\title{
ФОРМУВАННЯ НАВИЧОК ВИКОРИСТАННЯ СУБД ПРИ ОПРАЦЮВАННІ МЕДИКО-БІОЛОГІЧНИХ ДАНИХ
}

\author{
Павло Микитенко \\ кандидат педагогічних наук, доцент кафедри медичної і \\ біологічної фізики та інформатики \\ Національний медичний університет імені О.О. Богомольця, \\ м. Київ, Україна \\ ORCID ID 0000-0003-1188-4334 \\ mikitenko_p@npu.edu.ua
}

\begin{abstract}
Анотація. У статті наведено результати наукового дослідження з питань формування в майбутніх фахівців галузі охорони здоров'я навичок використання систем управління базами даних (СУБД) під час опрацювання медико-біологічних даних. Розкрито значення застосування інформаційних технологій і систем управління базами даних у майбутній професійній діяльності студентів-медиків. 3'ясовано особливості та загальні підходи забезпечення головних психолого-педагогічних умов ефективності інтерактивної лекції з теми «Системи управління базами даних. Проєктування медичних баз даних. Бази даних доказової медицини». Запропоновано структуру організації підсумкового практичного заняття «Побудова баз даних медичних закладів. Індивідуальні медичні картки. Структуризація змісту електронних медичних карток (ЕМК)» та методику формування навичок використання СУБД у ході опрацювання медико-біологічних даних. Розглянуто компетентнісно орієнтовані завдання із запропонованої теми, які мають різний рівень складності та представлено шкалу оцінювання навчальних досягнень, яка диференційована залежно від типу діяльності студента.

Ключові слова: система управління базами даних; медико-біологічні дані; методика навчання; фахівці в галузі охорони здоров’я.
\end{abstract}

Постановка проблеми в загальному вигляді. Опрацювання значних обсягів даних було та залишається однією з гострих проблем організації системи охорони здоров'я. Великі масиви даних можуть стати проблемою, якщо немає засобів їхнього аналізу та опрацювання. У 2017 р. Міністерством охорони здоров’ я Україна та низкою організацій було підписано меморандум про спільну розробку інформаційно-телекомунікаційної системи, що забезпечувала б автоматизацію введення обліку медичних послуг та управління медичними даними в електронному вигляді. До складу цієї системи «еHealh» входять центральна база даних (БД) та медичні інформаційні системи, між якими відбувається обмін даними через відкритий програмний інтерфейс. У 2019 р. у тестовому режимі запущено електронну медичну картку (ЕМК) пацієнта, завдяки цьому в майбутньому можна буде уникнути недоліків паперової медичної картки та забезпечити одночасний доступ до записів. Зокрема, форма $\mathrm{i}$ зміст ЕМК має відповідати певному затвердженому зразку. Збереження 
Формування навичок використання СУБД при опрацюванні медико-біологічних даних

сукупності даних у пам'яті комп'ютера та їхня організація в БД має ще одну перевагу, що може бути підставою для створення баз знань із можливістю інтелектуального пошуку та їхнього аналізу, бо кожного дня з'являється нова інформація про актуальні методи лікування, спеціалізовані лікарські препарати та таксономію захворювань.

Не можна стверджувати, що на сьогоднішній день завдання організації системи управління базами даних у структурі лікувального закладу розв'язане остаточно. Навчання теорії баз даних та формування відповідних навичок розробки реляційної моделі БД спрямовані на вирішення актуальних проблем у роботі закладів охорони здоров'я.

Аналіз останніх досліджень і публікацій. Основні поняття про дані та їхнє опрацювання висвітлено в праці датського вченого в галузі інформатики П. Науером (Naur, 1974). Концепції управління базами даних подані колективом авторів у праці «Database system concepts» (Silberschatz, Korth, Sudarshan, 2011).

Фундаментальні питання фахової підготовки майбутніх лікарів, розглядалися в працях І. Булах (2012), Ю. Вороненка (2017), I. Хаімзона (2007), а науковий та методичний супровід інформатичної підготовки майбутніх лікарів висвітлено в працях І. Кривенко (2014), Ю. Ляха (2006), Н. Попової (2015).

Провідні інформаційні системи в Україні, такі як: eZdorovya (https://ehealth.gov.ua) та DoctorEleks (https://doctor.eleks.com/ehealth) забезпечують виконання низки завдань, а саме: перехід на електронний облік (eрецепт, е-картка, е-направлення); створення нових електронних сервісів; упровадження новацій у медицині (machine learning, big data, blockchain).

За міжнародним стандартом ISO/IEC 2382:2015 база даних - це сукупність даних, які організовано відповідно до концепції, що описує характеристику цих даних і взаємозв'язки між їхніми елементами. Визначаючи зміст СУБД можна сказати, що це сукупність мовних і програмних засобів, призначених для створення, управління і спільного використання БД багатьма користувачами.

Формулювання цілей статті. 3 огляду на актуальність проблеми створення інформаційно-телекомуніційної системи в галузі охорони здоров'я та запровадження централізованої бази даних метою статті вбачаємо викладення загальних принципів і методики формування навичок використання СУБД у майбутніх фахівців галузі охорони здоров'я під час опрацювання медикобіологічних даних.

Результати дослідження. Процес формування навичок у студентів спеціальності 222 «Медицина» до використання СУБД під час опрацювання медико-біологічних даних починається з вивчення теми «Комп'ютерні дані. Типи даних, обробка та управління. Кодування та класифікація» та відбувається

Професіоналізм педагога: теоретичні й методичні аспекти. - Вип. 11. - Слов’янськ, 2019. 
Формування навичок використання СУБД при опрацюванні медико-біологічних даних

впродовж наступних двох занять, а саме: «Системи управління базами даних. Проєктування баз даних. Розробка реляційної моделі баз даних» та «Побудова баз даних медичних закладів. Індивідуальні медичні картки. Структуризація змісту ЕМК». Відповідно до робочої програми 3 дисципліни «Медична інформатика» тривалість кожного практичного заняття три академічні години, також закладено дві академічні години для лекції з теми «Системи управління базами даних. Проєктування медичних баз даних. Бази даних доказової медицини».

Як зазначає І. Головчак (2015), головними критеріями педагогічної та психологічної ефективності лекції є формування в студентів зацікавленості та мотивації, прояв емоційної реакції через подив, парадоксальність, переживання прикладу, виникнення пізнавальної потреби в подальшому самостійному пошуку, поштовх у професійному розвитку особистості майбутнього лікаря під впливом особистості фахівця викладача. Рівень підготовки студентів медиків орієнтує викладача на перехід від педагогічного традиціоналізму до впровадження нових форм і методів проведення лекційного заняття. Тому раціональним кроком $є$ проведення інтерактивної лекції, яка дає змогу поєднати керівну роль викладача 3 високою активністю студентів на базі використання сучасних інтерактивних технологій.

Для забезпечення головних психолого-педагогічних умов ефективності використання мультимедійних технологій під час проведення лекції 3 теми «Системи управління базами даних. Проєктування медичних баз даних. Бази даних доказової медицини» варто уникати перенавантаження лекцій слайдами. Кількість слайдів має бути такою, щоб відобразити найважливіший матеріал.

Зокрема, під час лекції відбувається ознайомлення студентів з основною концепцією БД, поняттям СУБД та їхніми особливостями, класифікацією БД та технологіями опрацювання даних, типами інфологічних моделей даних (ієрархічна, мережева, реляційна). 3 метою формування в студентів медиків цілісного уявлення про професійні сфери застосування інформаційних систем і баз даних розглядаються медичні ресурси, такі як: Medscape (налічує описи 6500 захворювань), MedlinePlus (одна з найбільших медичних бібліотек світу, містить дані в галузі охорони здоров'я), AgingPortfolio (Система управління знаннями в галузі старіння), Cochrane Library (містить дані ефективності медичних засобів та методик, що підтверджуються рандомізованими контрольними випробуваннями), DoctorElecs (інтегрована електронна медична карта пацієнта i система лікарських оглядів) (рис. 1). 
Формування навичок використання СУБД при опрацюванні медико-біологічних даних

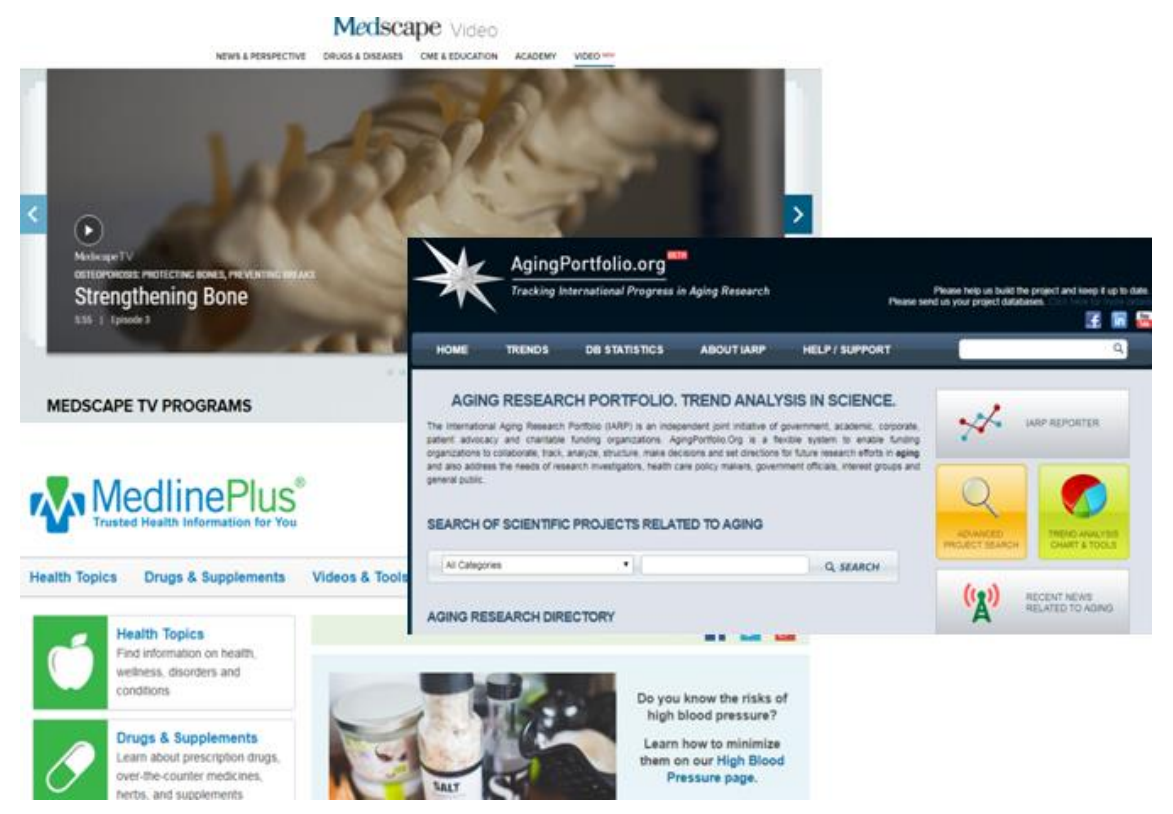

Рис. 1. Зразок медичних БД

Технологія організації, ведення та опрацювання медико-біологічних даних засобами реляційної бази даних під час лекції розглядається на прикладі MS Access (рис. 2). Проєктування БД відбувається безпосередньо з використанням ПЗ наприкінці лекційного заняття. Організація реляційної моделі даних допускає запис відомостей лише в один спосіб, а саме у вигляді таблиць. Кожний рядок таблиці містить дані, що стосуються конкретного об'єкта, які є набором фактів. Оскільки порядок стовпчиків вважається невизначеним, то їхні імена є єдиним засобом доступу до відповідного факту.

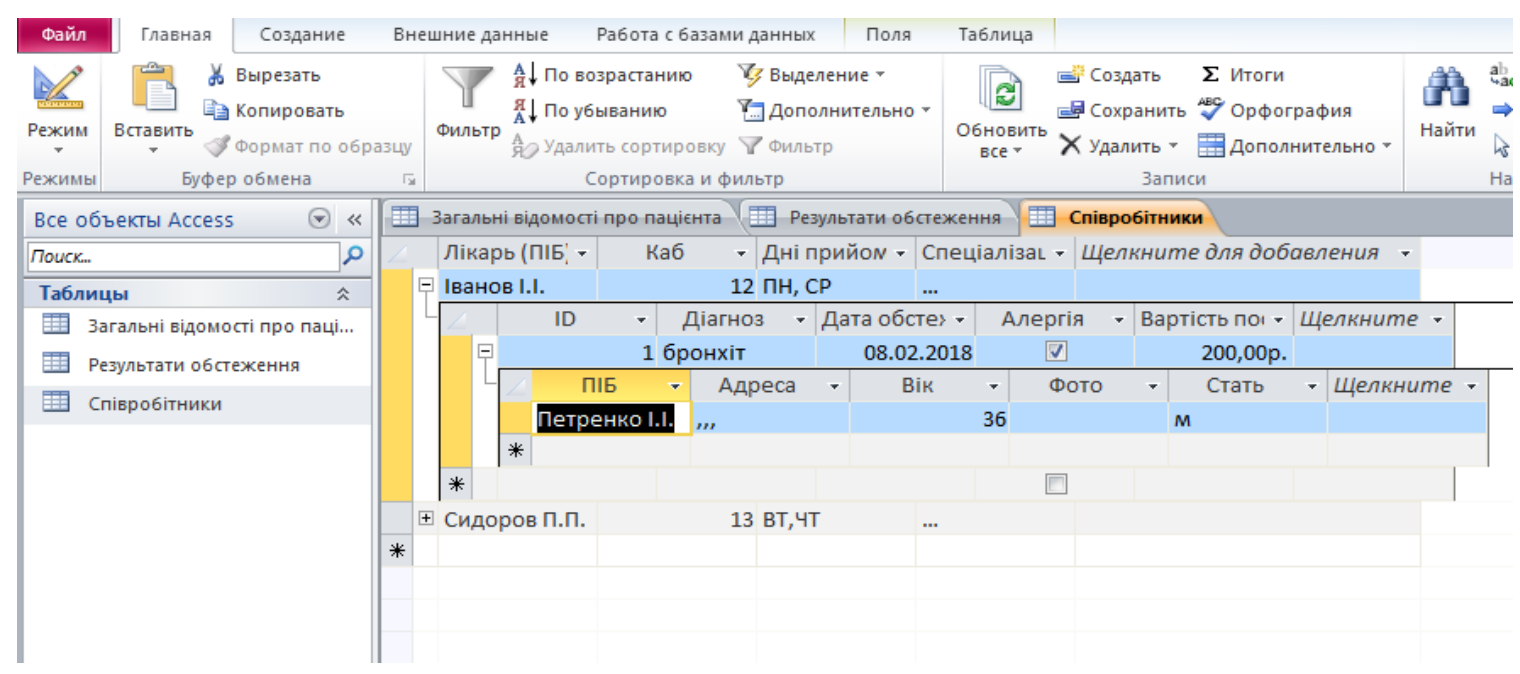

Рис. 2. Зразок БД створеної в MS Access

Професіоналізм педагога: теоретичні й методичні аспекти. - Вип. 11. - Слов’янськ, 2019. 
Формування навичок використання СУБД при опрацюванні медико-біологічних даних

Розглянемо організацію структури підсумкового практичного заняття «Побудова баз даних медичних закладів. Індивідуальні медичні картки. Структуризація змісту електронних медичних карток» (табл. 1), яке потребує наявності сформованих умінь і навичок із попередніх двох занять. До навчальних цілей заняття можна віднести формування:

- фахових компетентностей (називати типи даних; визначати характеристику даних; описувати структуру даних; класифікувати БД; з'ясовувати структуру СУБД; описувати основні функціональні характеристики СУБД Access; обирати типи даних для побудови ЕМК; застосовувати СУБД для побудови таблиць і запитів; розробляти ЕМК засобами СУБД Аccess; розділяти на етапи побудову ЕМК; аналізувати різні моделі даних; проєктувати ЕМК; встановлювати зв'язок між даними; аргументувати вибір засобів для розробки ЕМК; пояснювати етапи роботи в СУБД Access);

- загальних компетентностей (інструментальні компетентності: навички роботи з комп'ютером; навички управління інформацією; дослідницькі навички; здатність до аналізу й синтезу; здатність до організації та планування; вирішення проблем і прийняття рішень, розробка й управління проєктами, загальнонаукові компетентності: базові знання в галузі інформатики й сучасних інформаційних технологій; навички використання програмних засобів i навички роботи в комп'ютерних мережах, уміння створювати БД i використовувати інформаційні медичні ресурси, соиіально-особистісні компетентності: здатність до критики й самокритики; здатність до системного мислення, креативності, створення нових ідей; наполегливість у досягненні мети, здатність працювати самостійно; турбота про якість виконуваної роботи, прагнення до успіху).

Методи навчання, що застосовуються на практичному занятті, поділяються на класичні (інструктаж, пояснення, демонстрування, пошуковоевристичний, дослідницький) та сучасні (теоретична експрес-співбесіда, мозковий штурм, технології групового навчання, робота в малих групах).

Вивчення теми «Побудова баз даних медичних закладів. Індивідуальні медичні картки. Структуризація змісту електронних медичних карток» забезпечує попередню міждисциплінарну інтеграцію з «Медичною і біологічною фізикою» (студент повинен знати закони розподілу дискретних і неперервних випадкових величин і застосовувати методи математичної обробки медикобіологічних даних) та наступну 3 дисципліною «Логіка, формальна логіка» (студент повинен знати основи логічних операцій із типами даних і вміти встановлювати зв'язки між явищами та даними).

() ДВНЗ «Донбаський державний педагогічний університет» 
Таблиця 1

\section{Структура практичного заняття}

\begin{tabular}{|c|c|c|c|}
\hline Етапи заняття & $\begin{array}{c}\text { Методи } \\
\text { навчання та } \\
\text { контролю } \\
\end{array}$ & $\begin{array}{c}\text { Засоби методичного } \\
\text { забезпечення }\end{array}$ & Тривалість \\
\hline 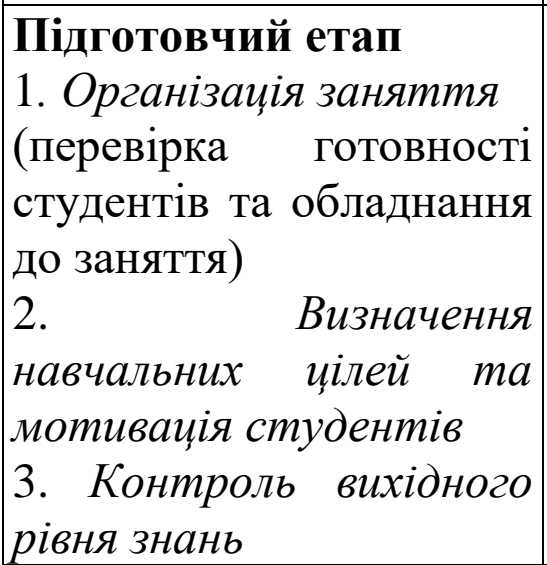 & $\begin{array}{c}\text { Інструктаж, } \\
\text { пояснення, } \\
\text { демонстрація, } \\
\text { тестовий } \\
\text { контроль, } \\
\text { мозковий штурм }\end{array}$ & $\begin{array}{c}\text { Презентація за темою } \\
\text { заняття, } \\
\text { мультимедійний } \\
\text { проєктор, } \\
\text { тестові завдання, } \\
\text { програма МуTest, } \\
\text { персональні } \\
\text { комп'ютери }\end{array}$ & $30 \mathrm{xB}$ \\
\hline $\begin{array}{l}\text { Основний етап } \\
\text { 4. Формування фахових } \\
\text { компетентностей } \\
\text { Оволодіти навичками } \\
\text { створення ЕМК: } \\
\text { - ознайомитися з } \\
\text { наявними ЕМК; } \\
\text { - ознайомитись } 3 \\
\text { інтерфейсом та } \\
\text { панеллю інструментів } \\
\text { програми СУБД } \\
\text { Ассемs; } \\
\text { - навчитися } \\
\text { працювати в СУБД } \\
\text { Ассемs; } \\
\text { - демонструвати } \\
\text { вміння створення ЕМК } \\
\end{array}$ & $\begin{array}{c}\text { Проблемно- } \\
\text { евристичний та } \\
\text { дослідницький } \\
\text { метод, } \\
\text { робота в малих } \\
\text { групах, } \\
\text { кейс-метод. }\end{array}$ & $\begin{array}{c}\text { Персональні } \\
\text { комп’ютери, } \\
\text { ОС Windows, } \\
\text { СУБД Access, } \\
\text { практикум із медичної } \\
\text { інформатики, } \\
\text { завдання для } \\
\text { інтерактивного } \\
\text { навчання }\end{array}$ & $80 \mathrm{XB}$ \\
\hline $\mid \begin{array}{ll}\text { Заключний етап } \\
5 . & \text { Контроль } \\
\text { корегування } & \text { рівня } \\
\text { професійних } & \text { вмінь } \quad \text { i } \\
\text { навичок } & \\
\text { Практична перевірка: } \\
\text { оцінюється } & \text { групова } \\
\text { діяльність студентів } \\
\text { 6. Підведення } \\
\text { підсумків } \\
\text { заняття: } & \text { вказати } \\
\end{array}$ & $\begin{array}{c}\text { Захист робіт, } \\
\text { взаємо- } \\
\text { опитування, } \\
\text { контроль } \\
\text { результатів, } \\
\text { індивідуальне } \\
\text { опитування, } \\
\text { мозковий штурм, } \\
\text { аналіз та } \\
\text { оцінювання }\end{array}$ & $\begin{array}{c}\text { Мультимедійний } \\
\text { проектор }\end{array}$ & 30 хв \\
\hline
\end{tabular}


Формування навичок використання СУБД при опрацюванні медико-біологічних даних

\begin{tabular}{|lr|c|l|l|}
\hline студентам на основні & викладачем & & \\
помилки; & оцінити & навчальної & & \\
студентів та виставити & діяльності & & \\
оцінки за заняття & студентів & & \\
\hline
\end{tabular}

3 метою формування необхідних навичок на практичному занятті студентам пропонуються компетентнісно орієнтовані завдання різного рівня складності. Наприклад, пропонується створити БД, яка б забезпечувала роботу діагностичної лабораторії. БД повинна містити загальні відомості про пацієнтів, які проходили обстеження в лабораторії (табл. 2), файли 3 результатами відповідних досліджень (табл. 3) і список співробітників лабораторії (табл. 4).

Таблиця 2

\section{Відомості про паціснтів}

\begin{tabular}{|l|l|l|c|c|c|c|}
\hline № & \multicolumn{1}{|c|}{ ПІБ } & $\begin{array}{c}\text { Дата } \\
\text { народження }\end{array}$ & Стать & Група крові & $\begin{array}{c}\text { Резус } \\
\text { фактор }\end{array}$ & К_С \\
\hline 1 & Пацієнт 1 & 21.04 .1966 & ч & А & + & 1 \\
\hline 2 & Пацієнт 2 & 12.11 .1937 & ж & В & - & 2 \\
\hline 3 & Пацієнт 3 & 04.05 .1985 & ч & А & - & 4 \\
\hline 4 & Пацієнт 4 & 27.02 .1977 & ж & 0 & - & 3 \\
\hline 5 & Пацієнт 5 & 23.08 .1943 & ч & АВ & + & 2 \\
\hline
\end{tabular}

Для створення бази даних необхідно створити модель таблиць (кількість стовпчиків, їхні назви, тип даних кожного стовпчика), встановити зв'язки між таблицями, заповнити таблиці даними відповідно до форм.

Таблиця 3

Результати досліджень

\begin{tabular}{|c|c|c|c|c|c|}
\hline № & Діагноз & $\begin{array}{c}\text { Аналіз } \\
\text { крові }\end{array}$ & Температура & Ендоскопія & 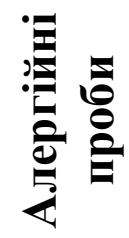 \\
\hline 1 & Кіста грудної стінки & & 36,6 & & $\nabla$ \\
\hline 2 & Периферійний рак & & 37,3 & & \\
\hline 3 & Хондрома ребра & & 36,7 & & $\nabla$ \\
\hline 4 & $\begin{array}{l}\text { Центральний } \\
\text { легені }\end{array}$ & & 37,2 & & $\nabla$ \\
\hline 5 & $\begin{array}{l}\text { Периферійний рак } \\
\text { легені }\end{array}$ & & 37,1 & & \\
\hline
\end{tabular}


Після створення БД необхідно виконати запити в режимі конструктора, наприклад, знайти відомості про пацієнтів (прізвище, рік народження), у яких діагноз «Рак» або «Кіста»; чоловіків, у яких вік не перевищує 50 років та група крові А; осіб пенсійного віку, що проходили обстеження в лабораторії та мають негативний резус фактор.

Таблиця 4

\section{Співробітники}

\begin{tabular}{|l|l|l|l|}
\hline К_C & $\begin{array}{c}\text { ПІБ } \\
\text { співробітника }\end{array}$ & Кабінет & Спеціалізація \\
\hline 1 & Співробітник 1 & 11 & \\
\hline 2 & Співробітник 2 & 12 & \\
\hline 3 & Співробітник 3 & 13 & \\
\hline 4 & Співробітник 4 & 14 & \\
\hline
\end{tabular}

Після успішного виконання попередніх завдань потрібно доукомплектувати базу даних діагностичної таблицею «Медико-біологічні дані», яка має містити такі відомості: зріст, вага, ЧСС, артеріальний тиск, ЧД, склад імуноглобулінів у крові (імуноглобулін $\mathrm{C}$, імуноглобулін $\mathrm{M}$, імуноглобулін А), дослідження аналізу крові (гемоглобін, еритроцити, ШОЕ).

База даних має забезпечити виконання таких завдань:

- введення і редагування відомостей про пацієнтів, які звертаються за медичною допомогою;

- автоматизація звітних операцій (формування звітів і запитів про медикобіологічні дані пацієнтів);

- оформлення медичних карток пацієнтів;

- візуалізація результатів діяльності медичного центру у вигляді діаграм і графіків;

- забезпечення захисту від введення неправильних даних (зокрема, дат у різних форматах), випадкових помилок.

Наступний крок, це створення ЕМК діагностичної лабораторії, яку студенти виконують за наведеною схемою (рис. 3). 


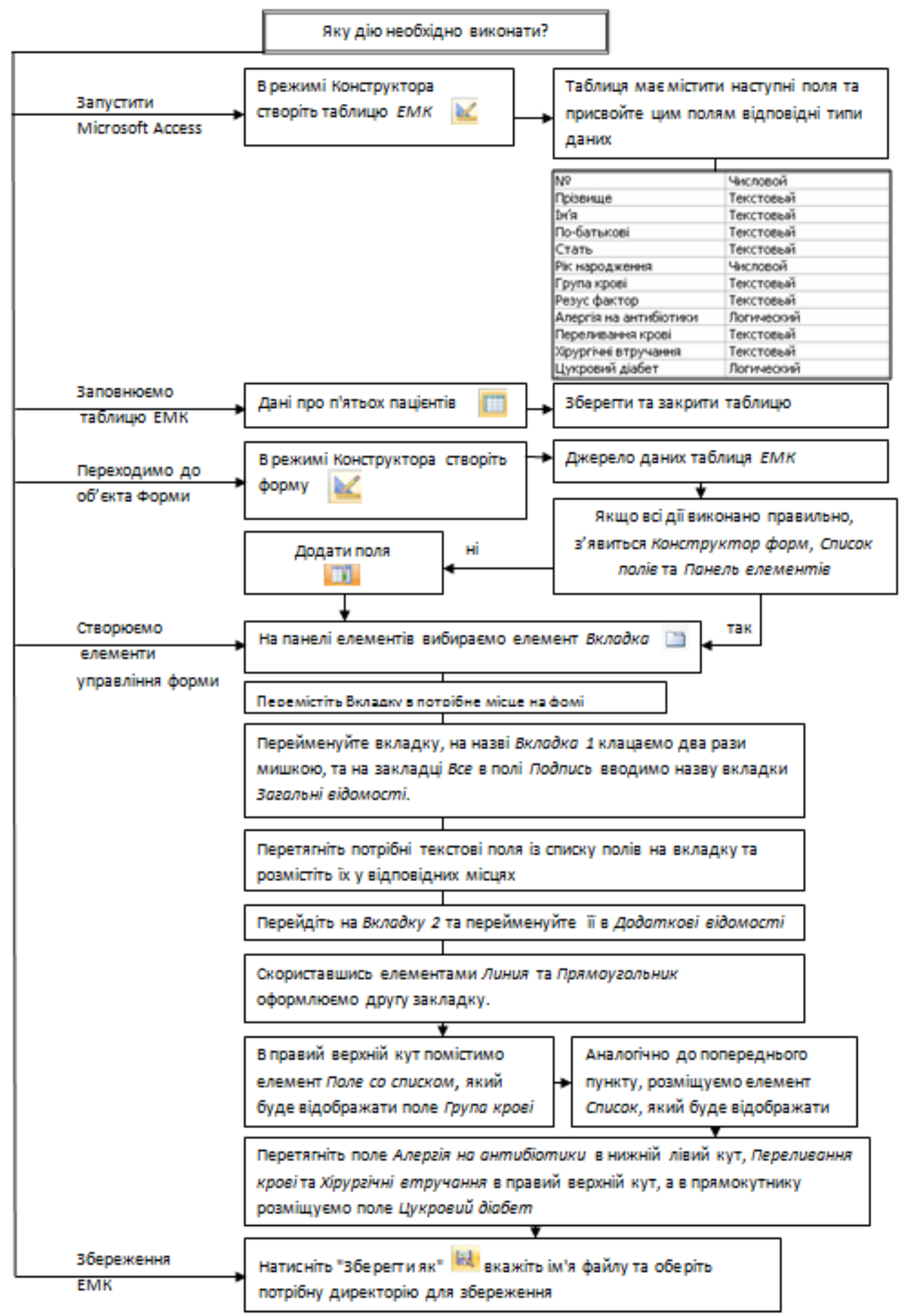

\section{Рис. 3. Схема створення ЕМК}

Далі кожна з підгруп студентів повинна опрацювати матеріали наданих їм кейсів та ввести в медичну картку додаткові поля відповідно до таблиці «Медико-біологічні дані». Після цього кожній із підгруп потрібно презентувати результати опрацьованих матеріалів. Завдання, розраховані для підгруп (по три особи), мають характер запитів, наприклад:

Завдання 1. Знайдіть відомості про пацієнтів: ПІБ, вік, жіночої статі, у яких 
Формування навичок використання СУБД при опрацюванні медико-біологічних даних

ШОЕ перевищує норму (норма 1 - 15 мм/год) та гемоглобін нижче норми (норма $120-140$ г/л).

Завдання 2. Знайдіть інформацію про пацієнтів: ПІБ, вік, чоловічої статі, у яких рівень еритроцитів у нормі (норма $4-5,5$ ), наявні хронічні захворювання та, які здавали біоматеріал у першу половину місяця.

Оцінювання студентів грунтується на результатах тестування та виконання практичних завдань, як визначення середньоарифметичного значення, за шкалою наведеною в табл. 5.

Таблиця 5

\section{Шкала оцінювання}

\begin{tabular}{|c|c|c|c|}
\hline & & & HO» \\
\hline 5 & 7 & 3 & $?$ \\
\hline \multicolumn{4}{|c|}{ Оцінювання результатів тестування } \\
\hline $\begin{array}{lr}\text { Студент } & \text { відповів } \\
\text { правильно на } 100- \\
91 \% & \text { тестових } \\
\text { завдань } & \\
\end{array}$ & \begin{tabular}{|lr} 
Студент & відповів \\
правильно & на $90-$ \\
$76 \%$ & тестових \\
завдань & \\
\end{tabular} & \begin{tabular}{|lr} 
Студент & відповів \\
правильно & на 75 - \\
$51 \%$ & тестових \\
завдань & \\
\end{tabular} & $\begin{array}{l}\text { нт відповів } \\
\text { льно на } 50 \text { і } \\
\text { е } \\
\text { зих завдань }\end{array}$ \\
\hline \multicolumn{4}{|c|}{ Оцінювання практичних навичок } \\
\hline $\begin{array}{l}\text { Студент успішно } \\
\text { демонструє } \\
\text { навички виконання } \\
\text { практичних } \\
\text { завдань різного } \\
\text { ступеня складності } \\
\text { (оволодів } \\
\text { практичними } \\
\text { навичками, що } \\
\text { передбачені } \\
\text { програмою) }\end{array}$ & $\begin{array}{l}\text { Студент } \\
\text { демонструє } \\
\text { практичні навички, } \\
\text { але допускає } \\
\text { незначні } \\
\text { непринципові } \\
\text { помилки, } \\
\text { суттєво які } \\
\text { впливають } \\
\text { кінцевий результат } \\
\text { роботи } \\
\end{array}$ & $\begin{array}{l}\text { Студент у процесі } \\
\text { виконання } \\
\text { практичних } \\
\text { завдань допускає } \\
\text { серйозні помилки, } \\
\text { може виконувати } \\
\text { лише типові прості } \\
\text { завдання }\end{array}$ & $\begin{array}{l}\text { Студент } \\
\text { оволодів } \\
\text { програмою, } \\
\text { допускає суттєві } \\
\text { помилки, не } \\
\text { сформовані } \\
\text { практичні } \\
\text { навички }\end{array}$ \\
\hline \multicolumn{4}{|c|}{ Оцінювання усної відповіді } \\
\hline $\begin{array}{l}\text { Студент глибоко і } \\
\text { повноцінно засвоїв } \\
\text { матеріал, } \\
\text { послідовно } \\
\text { логічно } \\
\text { обгрунтовує свою } \\
\text { відповідь. } \\
\text { Студент успішно } \\
\text { виконує різні види } \\
\text { завдань, правильно }\end{array}$ & $\begin{array}{lr}\text { Студент } & \text { засвоїв } \\
\text { матеріал } & \text { на } \\
\text { достатньому } & \text { рівні, } \\
\text { правильно } & \\
\text { відповідає } & \text { на } \\
\text { питання, } & \text { не } \\
\text { допускає } & \text { суттєвих } \\
\text { помилок } & \text { у } \\
\text { відповідях, } & \\
\text { правильно } & \\
\end{array}$ & $\begin{array}{lr}\text { Студент має знання } \\
\text { основного } \\
\text { матеріалу, але не } \\
\text { засвоїв } \\
\text { деталей, } \\
\text { помилки, допускає } \\
\text { достатньо } \\
\text { правильно } \\
\text { формулює } \\
\text { відповіді, порушує } \\
\end{array}$ & $\begin{array}{l}\text { Студент не знає } \\
\text { програмного } \\
\text { матеріалу, } \\
\text { допускає } \\
\text { помилки, } \\
\text { невпевнений у } \\
\text { своїй відповіді }\end{array}$ \\
\hline
\end{tabular}

Професіоналізм педагога: теоретичні й методичні аспекти. - Вип. 11. - Слов'янськ, 2019. 
Формування навичок використання СУБД при опрацюванні медико-біологічних даних

\begin{tabular}{|c|c|c|c|}
\hline $\begin{array}{l}\text { обгрунтовує } \\
\text { прийняті рішення }\end{array}$ & \begin{tabular}{|ll} 
використовує & \\
теоретичні \\
положення \\
виконанні \\
практичних \\
завдань
\end{tabular} & $\begin{array}{l}\text { послідовність } \quad \text { у } \\
\text { викладенні } \\
\text { матеріалу }\end{array}$ & \\
\hline \multicolumn{4}{|c|}{ Оцінювання активності студентів } \\
\hline Проактивний & Активний & Малоактивний & Пасивний \\
\hline $\begin{array}{l}\text { Студент бере } \\
\text { активну участь у } \\
\text { обговоренні } \\
\text { питань, } \\
\text { аргументовано } \\
\text { відстоює свою } \\
\text { думку, } \\
\text { винахідливий, } \\
\text { комунікативний і } \\
\text { вільно працює в } \\
\text { команді }\end{array}$ & $\begin{array}{lr}\text { Студент } & \text { бере } \\
\text { участь } \\
\text { обговоренні } \\
\text { питань, не } \\
\text { відстоює завжди } \\
\text { думку, працює в } \\
\text { команді }\end{array}$ & $\begin{array}{l}\text { Студент не завжди } \\
\text { бере участь в } \\
\text { обговоренні } \\
\text { питань, не завжди } \\
\text { відстоює свою } \\
\text { думку, працює в } \\
\text { команді }\end{array}$ & $\begin{array}{l}\text { Студент не } \\
\text { участі } \\
\text { обговоренні } \\
\text { питань, не має } \\
\text { своєї думки, } \\
\text { невпевнений у } \\
\text { собі, не працює } \\
\text { на занятті }\end{array}$ \\
\hline
\end{tabular}

Висновки 3 дослідження і перспективи подалыших розвідок у цьому напрямі. Отже, вивчення зазначеної теми та формування навичок використання СУБД у майбутніх фахівців галузі охорони здоров'я під час опрацювання медико-біологічних даних за викладеними принципами має сприяти виконанню низки завдань дисципліни «Медична інформатика», які полягають у формуванні та розвитку знань, умінь і навичок, необхідних для ефективного використання прикладного програмного забезпечення (MS Access) у галузі охорони здоров'я, ознайомлення студентів із значенням та можливостями нових інформаційних технологій, розвитку вміння самостійного опанування програмних засобів загального призначення, формування базових навичок щодо пошуку медичних даних із використанням інформаційних технологій та навичок використання методів опрацювання медико-біологічних даних.

Перспективи подальших досліджень убачаємо в розроблені теоретичних і методичних засад формування цифрової компетентності майбутніх фахівців у галузі охорони здоров'я.

\section{СПИСОК ВИКОРИСТАНИХ ДЖЕРЕЛ}

1. ISO/IEC 2382:2015 Information technology - Vocabulary. Retrieved from https://www.iso.org/standard/63598.html

2. Naur P. (1974). A Basic Principle of Data Science. Concise Survey of Computer Methods. Lund. 
Формування навичок використання СУБД при опрацюванні медико-біологічних даних

3. Silberschatz A., Abraham H., \& Sudarshan S. (2011). Database system concepts. New York, the USA: McGraw-Hill.

4. Булах І.Є., Лях Ю.Е., Марценюк В.П. і Хаимзон И.И. (2012) Медицинская информатика. Учебник. Киев, Украина: ВСИ «Медицина».

5. Воровенко Ю. В., Мінцер О. П. Медична інформатика $і$ кібернетика в охороні здоровя та медицині. Взято з https://ojs.tdmu.edu.ua/index.php/ here/article/download/7891/7463.

6. Головчак I. С. (2015). Сучасна лекція. Галицький лікарський вісник, 22, 100-101.

7. Кривенко I. П. (2014). Модель формування у майбутніх лікарів компетентності $з$ опрацювання медико-біологічних даних у процесі вивчення дисципліни «Медична інформатика». Гуманітарний вісник ДВНЗ. (С. 93-100). Київ: Гнозис.

8. Лях Ю.Е., Гурьянов В.Г. и Хоменко В.Н. (2006). Основы компьютерной биостатистики. Д. $211 \mathrm{c.}$

9. Попова Н.М. и Сабитова Н.Г. (2015). Решение практических задач по дисциплине «медицинская информатика» с помощью информационных технологий. Здоровье, демография, экология финно-угорских народов, 2, 54-55.

10. Хаїмзон I.I. (2007) Медичні знання та прийняття рішень в медицині. Вінниця: BHTУ.

\title{
FORMING THE SKILLS OF USING DATABASE MANAGEMENT SYSTEM IN THE PROCESSING OF BIOMEDICAL DATA
}

\author{
Pavlo Mykytenko \\ Ph.D., Associate Professor of Medical and Biological Physics and Informatics \\ Biological Physics and Informatics Department \\ Bogomolets National Medical University \\ Kiev, Ukraine \\ ORCID ID 0000-0003-1188-4334 \\ mikitenko_p@npu.edu.ua
}

\begin{abstract}
The article presents the results of scientific research on forming the skills of the using of database management systems in the processing of biomedical data for future healthcare professionals. We revealed the importance of application of information technologies and database management systems in the future professional activity of medical students. Taking into consideration the relevance of the issue of creating the information and telecommunication systems in the sphere of health care and implementing the centralized database, the purpose of the article is to describe the general principles and methods of developing future specialists' skills of using database management systems while processing medical and biological data.

The peculiarities and general approaches of providing the main psychological and pedagogical conditions for the effectiveness of an interactive lecture on the topic "Database management systems. Designing medical databases. Evidence Based Databases". We have proposed the structure of the organization of the final seminar "Creation of databases for medical establishments. The patient records. Structuring the computer-based patient record" and methods of forming the skills of using database management systems in the processing of biomedical data. The following stages are singled out in the structure of the seminar: introductory stage (checking the students' readiness and knowledge level); main stage (developing professional competences concerning the work with database); final stage (controlling and correcting the level of the development of professional skills). We also considered competency-oriented tasks on the proposed topic, which have different levels of complexity and present a scale of assessment of academic achievement, which is differentiated depending on the type of student's activity.
\end{abstract}

Професіоналізм педагога: теоретичні й методичні аспекти. - Вип. 11. - Слов’янськ, 2019. 
Формування навичок використання СУБД при опрацюванні медико-біологічних даних

Key words: database management system; medical and biological data; teaching methods; health professionals.

\section{REFERENCES}

1. ISO/IEC 2382:2015 Information technology - Vocabulary. Retrieved from https://www.iso.org/standard/63598.html

2. Naur, P. (1974) A Basic Principle of Data Science. Concise Survey of Computer Methods. Lund.

3. Silberschatz, A., Abraham, H., \& Sudarshan, S. (2011). Database system concepts. New York, the USA: McGraw-Hill.

4. Bulax, I. Ye., Lyax, Yu.E., Marcenyuk, V.P. \& Xay`mzon, Y.Y. (2012). Medical informatics. Tutorial. Kyiv, Ukraine: VSI "Medetsina".

5. Vorovenko, Yu.V. \& Mincer, O.P. Medical Informatics and Cybernetics in Health Care and Medicine. Retrieved from https://ojs.tdmu.edu.ua/index.php/here/article/download/7891/7463

6. Golovchak, I.S. (2015). Modern lecture. Galician Medical Bulletin, 22, 100-101.

7. Kryvenko, I.P. (2014). Model of formation in future doctors of competence for processing of medical and biological data in the course of studying the discipline "Medical Informatics". Humanitarian Herald of the State Pedagogical University. (P. 93-100). Kyiv: Gnosis.

8. Lyax, Yu.E., Gur'yanov, V.G. \& Khomenko V.N. (2006) Basics of computer biostatistics. D.

9. Popova, N.M., Sabytova, N.G. (2015). Solution of practical problems in the discipline "medical informatics" with the help of information technologies. Health, demography, ecology of Finno-Ugric peoples, 2, 54-55. VNTU.

10. Xayimzon I.I. (2007) Medical knowledge and decision making in medicine. Vinnitsa:

Матеріали надійшли до редакції 22.09.2019 р. 